\title{
微生物対策と水の有効利用*
}

\author{
栗田工業株式会社 水処理事業部 杉 卓 美
}

\section{Fungicide and Water Reuse in the Pulping Process}

Takumi Sugi

Water Treatment Division, KuritaWater Industries Ltd.

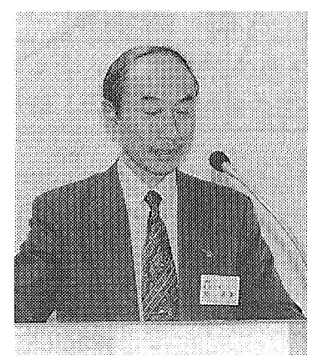

Main biological problem in pulping process is fungi deposition on pulp sheet. Fungicides are generally used to prevent fungi deposition. Fungicides and the application method are described.

In adition, it is becoming more important to recover the effluent and reuse it in the deinking process. But this effluent is difficult to treat because it has high $\mathrm{pH}$ and contains fine suspended solids. The coagulation method, using a high charged cationic polymer can get rid of fine particles and give clear recycling water. As a result it has such advantages as high brigtness, high strength of DIP and preventinng pitch problem.

分類： $W_{13}$ スライムコントロール剂, $G_{5}$ 脱インキ, $\mathrm{X}_{1}$ 排水

\section{1.はじめに}

パルプ化工程における微生物障害としては，パルプ のカビによる污染，脱墨工程における漂白剤の分解， スライム障害などがある。これらの微生物障害は，抄 紙工程に抢けるスライム障害とは状況が異なっており 対策も異なる。

一方，パルプ化工程では大量の水が使用されている。 特に近年, 脱墨処理設備の新設, 増強に伴い, 脱墨工 程での水の使用量が増大し, 水の確保が重要な課題と なっている。同時に排水量も增加し, 排水処理の負荷 もいっそう増大している。脱墨工程の排水は, 抄紙工 程から排出されている水と異なり, $\mathrm{pH}$ が高く, 界面 活性剂を含み，微細の繊維，填料を多く含むなど，処 理しにくい水でもある。しかし，水の確保，排水量低 減の観点から，大量に排出される水は再利用されるべ

*「パルプ化工程使用薬品セミナー」講演
きであり，また，再利用するにあたり，効率よく処理 する必要がある。

本セミナーでは微生物障害に関してはパルプの防カ ビ処理を中心に, また, 水の有効利用として脱墨工程 排水の再利用について概説する。

\section{2. 微生物対策}

2.1 パルプの防カビ”

2.1.1 カビによる障害

KP, TMP，DIPは通常水分を約 50\% 含有した湿 潤パルプとして利用されている。これらのパルプが外 販されたり, 他工場で使用される場合, 使用されるま でかなりの日数が経過する。特に，5９月の梅雨期 をはさんだ滞貨時にカビ污染の問題が生じる。つまり， パルプシート上に黑色, 緑色, 茶色などのカビの発育 （写真 1）に伴うシミが生じて商品価值が低下すると ともに，セルロースが分解されて，パルプ強度が低下 する場合もある。特に，栄養源を多く含む脱墨パルプ 


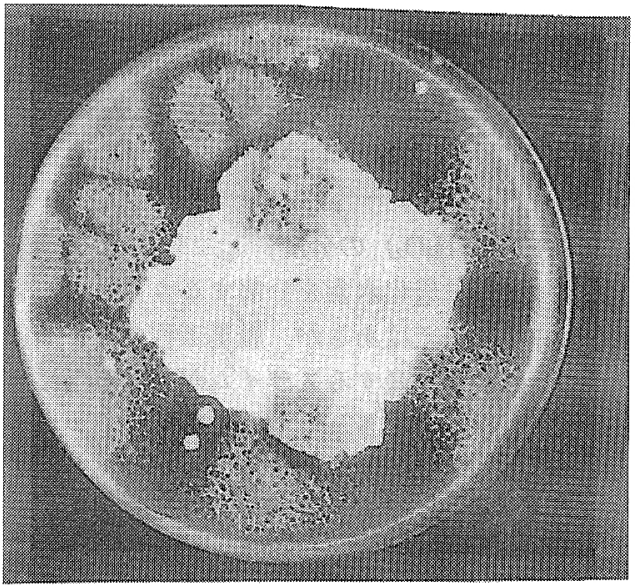

写真 1 パルプに発生するカビ

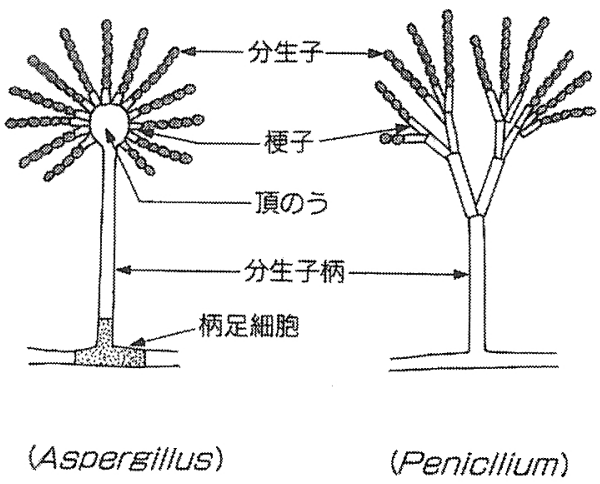

図 1 カビの形態
の場合，力ビが発生しやすい。

\section{1 .2 カビの種類と生育条件}

カビは菌体が糸状を呈するので糸状菌ともいわれ， 菌系からなる菌系体と，それから伸びる気中菌糸の先 端に形成される胞子とからなる（図 1，写真 2）。力ビ に種々の色調があるのは，これらの胞子の色によるも のである。

パルプ上に生育しやすいカビとしては, セルロース 分解菌として知られる Trichoderma sp.の他, 一般 的なカビとして Aspergillus sp., Mucor sp., Penicilliumsp., Rhizopus sp.などが見出されている。

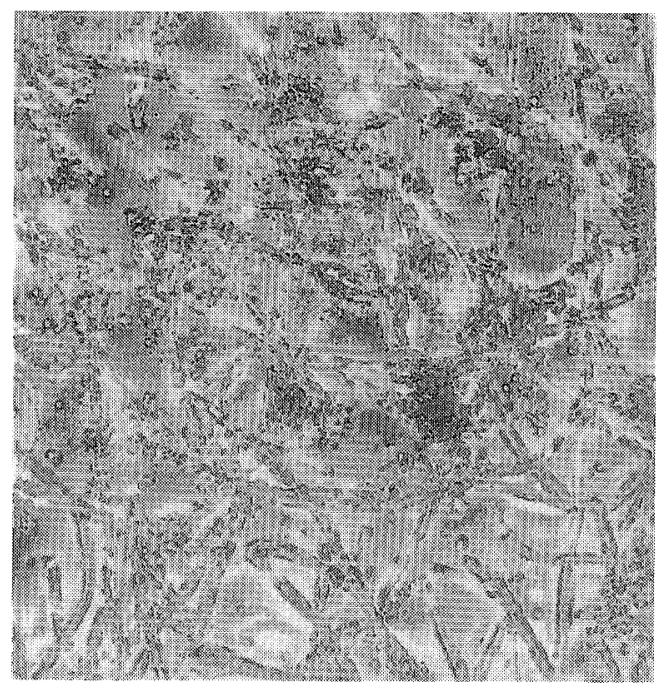

写真 2 カビの菌系

表 1 カビと細菌の生育条件

\begin{tabular}{l|l|l}
\hline \multicolumn{1}{c|}{ 生育条件 } & \multicolumn{1}{|c|}{ か び } & \multicolumn{1}{|c}{ 細 } \\
\hline \multicolumn{1}{c|}{ 菌 }
\end{tabular}


カビと細菌の生育条件の比較を表 1 に示す。白水と 比較して温度が低く, 水分や栄養源が少ないパルプ上 においては，細菌よりむしろカビの方が生育しやすい。

\section{1 .3 防カビ方法}

実用的な方法として，防カビ剂をパルプに内添する 方法，外添する方法がとられている。

(1) 防カビ剤

一般に使用されている防力ビ素材を表 2 に示す。べ ンズイミダゾール系，ダコニール，IPBCなどが主に 使用されている。これらの素材は, 殺カビ作用より, 増殖抑制作用を有しており，低濃度ではあるが長期間 にわたりパルプ内に残留し，カビの増殖を抑制する。

また，次項で記すように，パルプへの歩留を向上さ せるため水に難溶性の素材が一般に用いられる。さら に，抗菌スペクトルを広げるため数種の防カビ素材を 配合して製剤化される。

(2) 添加方法

a. 内 添 法

原料パルプスラリーに防カビ撤 $(0.05 \sim 0.1 \%$ 対パ ルプ）を添加し，脱水工程を経て湿潤パルプとしてす き上げられたときに，有効濃度の防カビ剤が含有され るようにする方法である。長所として

(1)添加作業が簡便

(2)シート全体に均一に処理できる

等がある反面,

(3)シートへの歩留

が問題となる。歩留を向上させるため，水に溶解しに くい防カビ素材が懸濁液の形に製椷され（フロアブル 剤）使用されている。

b. 外 添 法

通常プレス工程で防カビ剤の希釈液を散布する方法 である。長所としては

(1)薬剤の損失が少ない

等がある反面

(2)薬剤ミス卜飛散時の吸入, 経皮毒性, 臭気

(3)シート切断面への処理不十分

等の問題がある。

\section{1 .4 評価方法}

一般に加速試験方法として, JIS Z 2911「カビ抵抗 性試験方法」に準じた方法が寒施されている。この方 法は, 内添あるいは外添法で机上で作成した防カビ処 理済みのパルプシートを寒天培地上に置き，カビの発 生の有無を観察する方法である。パルプ内にカビが少 ない場合は，上からカビの胞子を添加して評価する。

評価結果を写真 3 に示す。防腐防カビ剂フィブサイ ド（FS-KF 583）が添加されたパルプはカビの発生が
認められない。なお，フィブサイドは，良好な防カビ 作用は有しているが, 水溶性のためパルプ用防カビ素 材として適用できなかったMIT（表 2）を，包接化 （図 2）することにより，水溶性を低隇させ歩留向上 を図った商品である。

\section{2 漂白剤 $\left(\mathrm{H}_{2} \mathrm{O}_{2}\right)$ の分解}

生物は一般に過酸化水素を分解するカタラーゼを生 産する。特殊な例ではあるが, 脱墨工程の夕ワー内に カタラーゼを多く生産するスライムが発生し, 添加さ れた過酸化水素が分解され白色度が向上しない場合が ある。タワー内 $\mathrm{pH}$ は高いため, 高 $\mathrm{pH}$ で分解せず, かつ, 高 $\mathrm{pH}$ ほど殺菌速度が向上するスライムコント ロール剤（クリノックス710）が使用される。

\section{3. 脱墨工程排水の再利用}

\section{1 脱墨工程における水の循環}

図 3 に脱墨工程のフロー図を示す。脱墨工程は原料 古紙をスラリー化し，インキをパルプから剥離させる 離解, ニーディングの工程, 過酸化水素などでパルプ を漂白する漂白工程，インキとパルプを分離するフロ ーテーション, 洗浄の工程からなる。

離解, ニーディングの工程では, パルパーでの離解 促進，ニーダーでのインキ剥離を目的として，苛性ソ ーダ，ケイ酸ソーダなどのアルカリ薬剤と界面活性剤 （脱墨剤）が使われている。フローテーションの工程 では，インキがパルプより疎水性が強いのを利用して， パルプスラリーにエアーを送り达みインキだけを浮上 させる目的で, 界面活性剂 (脱墨剤) が使用されてい る。洗浄工程はパルプスラリーの濃縮（脱水）と希釈 を繰り返して，パルプからインキを洗い流す工程であ り，パルプの希釈水や洗浄機のシャワー水として大量 の水を使用している。

このように種々の薬剤を用い，大量の水を使用する 脱墨工程では, 脱水機からのろ液, フローテーターで の浮上スカム（フロス）などの排水が生ずるが,

(1)添加薬剤の再利用

(2)新水使用量の削減

(3) $\mathrm{pH}$ が高い水なので排水処理が困難 などの点から，排水は再び脱墨工程に戻され，循環使 用されている場合が多い。

水の循環系は前段と後段の 2 系列に大別される。前 段とは，パルパーとニーダーの間にあるシリンダープ レスなどの脱水機から出てくるろ液（前段白水）を， 再びパルパーでの仕込水や，パルパー後の希釈水に戻 す循環系である。後段とは，フローテーターの後にあ るエキストラクターやバルブレスフィルターなどの洗 
表 2 防カビ素材

\begin{tabular}{|c|c|c|}
\hline $\begin{array}{l}\text { 化 } \\
\text { 合 } \\
\text { No. }\end{array}$ & $\begin{array}{l}\text { 防力ビ剂有効成分 } \\
\text { の構造式 }\end{array}$ & 化合物名 \\
\hline I & & 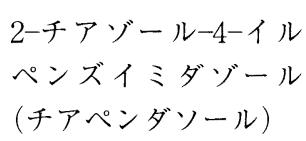 \\
\hline II & $\mathrm{OCH}_{3}$ & $\begin{array}{l}\text { メチルペンズイミダゾ } \\
\text { ール-2-イルカルバメ } \\
\text { ート }\end{array}$ \\
\hline III & $\begin{array}{l}\mathrm{Cl}_{2} \mathrm{~F} \\
{ }_{2} \mathrm{~N}\left(\mathrm{CH}_{3}\right)_{2}\end{array}$ & 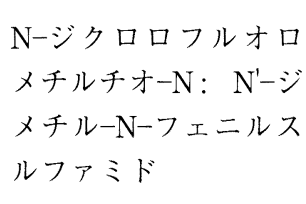 \\
\hline IV & 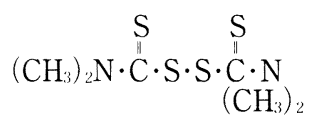 & $\begin{array}{l}\text { テトラメチルチウラム } \\
\text { ジサルファイド }\end{array}$ \\
\hline $\mathrm{V}$ & & $\begin{array}{l}\mathrm{N}-(\text { トリクロロメチル } \\
\text { チオ)-4-シクロヘキセ } \\
\text { ン-1,2-ジカルボキシ } \\
\text { イミド }\end{array}$ \\
\hline VI & & $\begin{array}{l}2,4,5,6-\text { テトラクロロ } \\
1,3-\text { } \text {-ソフタロニリ } \\
\text { ル (ダコニール })\end{array}$ \\
\hline
\end{tabular}

\begin{tabular}{|c|c|c|}
\hline $\begin{array}{l}\text { 化 } \\
\text { 合 } \\
\text { 物 } \\
\text { No. }\end{array}$ & $\begin{array}{l}\text { 防カビ剂有効成分 } \\
\text { の構造式 }\end{array}$ & 化合物名 \\
\hline VII & & $\begin{array}{l}2,3,5,6-\text { - トラクロロ } \\
-4-(\text { ×ルスルホニ } \\
\text { ル)ピリジン }\end{array}$ \\
\hline VII & & $\begin{array}{l}2-\mathrm{n}-オ ク チ ル-4-イ ソ \\
\text { チアゾリン-3-オン }\end{array}$ \\
\hline IX & $\mathrm{CHI}_{2}$ & $\begin{array}{l}\text { ジョードメチル-P-ト } \\
\text { リルスルホン }\end{array}$ \\
\hline X & $\mathrm{IC} \equiv \mathrm{C}-\mathrm{CH}_{2}-\mathrm{O}-\stackrel{\mathrm{I}}{\mathrm{C}} \cdot \mathrm{H}-\mathrm{N}_{4} \mathrm{~N}_{9} \cdot \mathrm{n}$ & 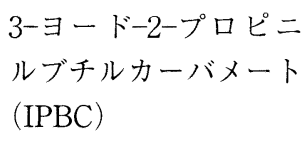 \\
\hline XI & & $\begin{array}{l}\text { 5-クロロ-2-メチル-4- } \\
\text { イソチアゾリン-3-オ } \\
\text { ン.2-メチル-4-イソチ } \\
\text { アゾリン-3-オン } \\
\text { (MIT) }\end{array}$ \\
\hline XII & & $\begin{array}{l}\text { 10,10-オキシビスフェ } \\
\text { ノキシアルシン }\end{array}$ \\
\hline
\end{tabular}




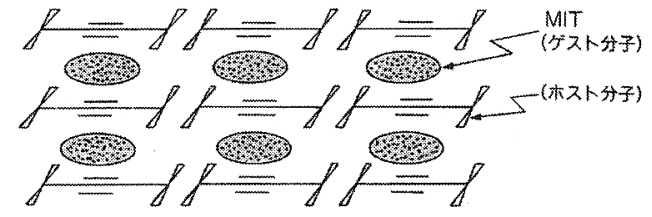

図 2 MTT の結晶格子状包接化合物

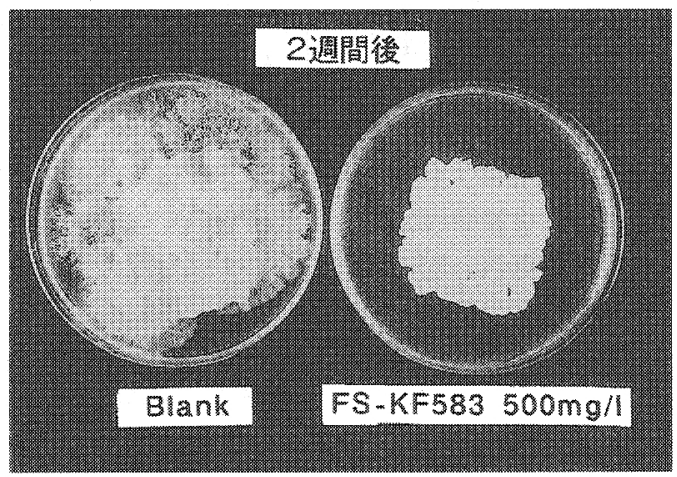

写真 3 防力ビ試験評価結果
浄機から出るろ液（後段白水）を, 夕ワー出口の希釈 水や, 洗浄機での希粎水に使用する循環系である。

\section{2 脱墨排水の特徵}

脱墨工程からの主な排水としては，1）前段白水の 余剩水，2）フロス，3）後段白水の余剩水の 3 つがあ る。表 3 に各排水と抄紙系排水の水質分析結果を示市。 脱墨工程の排水は次のような特徴を有している。

(1)アルカリ薬剤を使用しているので $\mathrm{pH}$ が高い。

(2)インキ, 灰分などの微細な SSが多くコロイド状 に分散している。

(3)新聞紙の原料である機械パルプ由来のリグニン, コート紙由来のラテックス，脱墨工程で添加され るアルカリ䊧剂などにより，アニオン性の成分が 非常に多く，ゼー夕電位は低くなっている。

特に前段白水は高 $\mathrm{pH}$ で，アニオン性成分，灰分が ともに多い高濃度の排水である。フロスはインキと界 面活性剤が多く, 発泡しやすい排水である。後段白水 は比較的繊維分があり，前段白水を希釈したような排

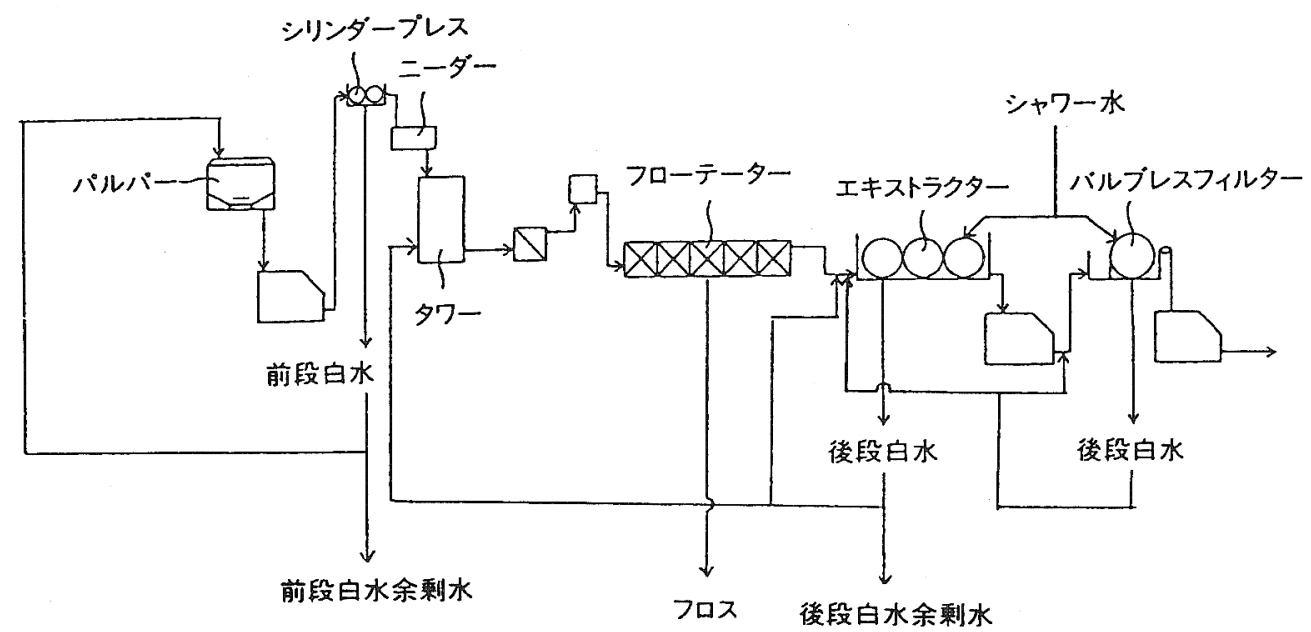

図 3 脱墨工程のフロー

表 3 脱墨工程排水と抄紙白水の水質

\begin{tabular}{l|r|r|r|r|c}
\hline & $\mathrm{pH}$ & $\begin{array}{c}\mathrm{SS} \\
(\mathrm{mg} / \mathrm{L})\end{array}$ & $\begin{array}{r}\text { 师分 } \\
(\mathrm{mg} / \mathrm{L})\end{array}$ & $\begin{array}{r}\text { ゼータ電位 } \\
(\mathrm{mV})\end{array}$ & $\begin{array}{c}\text { エロイド当量 } \\
(\mathrm{meq} / \mathrm{g})\end{array}$ \\
\hline 前段白水 & 10.5 & 7,500 & 5,800 & -35 & -0.6 \\
\hline フロス & 9.4 & 15,200 & 9,730 & -25 & -0.3 \\
\hline 後段白水 & 8.9 & 1,600 & 530 & -22 & -0.2 \\
\hline 中性上質紙白水 & 7.3 & 2,300 & 1,000 & -11 & -0.04 \\
\hline 酸性上質紙白水 & 5.1 & 2,000 & 800 & 0 & 0 \\
\hline クラフト紙白水 & 4.9 & 650 & 100 & -3 & -0.01 \\
\hline
\end{tabular}


水であり，非常に水量が多い。

\section{3 前段・後段白水の処理方法}

一般に, 凝集処理を行い加圧浮上または沈降処理で 固液分離するか，フローテーション処理を行う。凝集 にはアニオン一カチオンの反応であるイオン結合の力 に加えて，水素結合の力を利用する場合もある。

脱墨工程排水の凝集処理は抄紙系の白水回収と比較 して以下の特徵がある。

(1)インク, 灰分, ラテックスなどの微細な粒子が分 散状態にあるので, 高分子ポリマーだけでは凝集 しない。そこで, 硫酸バンド, カチオン性荷電調 整剂, ベントナイトなどで一次凝集させてから, 高分子ポリマーで二次凝集させる必要がある。

(2)ただし，非常にアニオン性成分が多いので，荷電 中和に硫酸バンドやカチオン性荷電調整剂が多量 に必要である。

(3)pH が高いので，カチオンポリマーを使用する場 合は, 高 $\mathrm{pH}$ 域でもカチオン価を失わない 4 級ア ミン系でなければならない。

(4)処理水を脱墨工程で再利用する場合は, アルカリ 薬剤と反応して $\mathrm{pH}$ を低下させたりアルミ，シリ カスケールを発生させたりするので, 硫酸バンド は使用できない。
表 4 に主な処理方法を示す。硫酸バンドまたはカチ オン性荷電調整剤で一次凝集し, 高分子アニオンポリ マーで二次凝集させるのが一般的であり, その概念図 を図 4 に示す。

ベントナイトやノニオンポリマーなどによる水素結 合を利用した処理は，イオン結合を利用した処理より 除濁性が劣るが, 排水の水質（pH，アニオン性）の 影響を受けにくく, 薬荗添加量が少なくてすむ場合が 多い。

\section{4 処 理 例}

\subsection{1 新聞古紙}

図 5 に新聞古紙脱墨工程の前段白水を, ハイホール ダー603（カチオン性荷電調整郕）とハイホールダー 356 (アニオンポリマー) で凝集させ, 加圧浮上処理 したときの, 処理水とハイホールダー 603 添加量の関 係を示す。同じく後段白水を, 八イホールダー 603 と ハイホールダー342（低カチオンポリマー）処理した 時の結果を示す。

$\mathrm{pH}$ が高く，アニオン性成分が多い前段では，八イ ホールダー 603 を $80 \mathrm{mg} / \mathrm{L}$ 添加することにより, 約 90\%の SS が除去できた。比較的 $\mathrm{pH}$ が低くアニオン 性成分が少ない後段では，ハイホールダー 603 を 13 $\mathrm{mg} / \mathrm{L}$ 添加することにより効果を示し, 得られた処理

表 4 主な脱墨排水の処理方法

\begin{tabular}{|c|c|c|c|c|c|}
\hline 一次凝集 & 二次凝集 & 前段 & フロス & 後段 & 再利用 \\
\hline 硫酸バンド(イオン結合) & アニオンポリマー(イオン結合) & $\triangle$ & (a) & $\bigcirc$ & $x$ \\
\hline カチオン性荷電調整剤 (イオン結合) & アニオンポリマー(イオン結合) & $\bigcirc$ & $\bigcirc$ & $\bigcirc$ & O \\
\hline カチオン性荷電調整剤 (イオン結合) & $\begin{array}{l}\text { 低カチオンポリマー(イオン・水 } \\
\text { 素結合) }\end{array}$ & $x$ & $\triangle$ & O & $\bigcirc$ \\
\hline $\begin{array}{l}\text { ベントナイト(水素結合, ファンデル } \\
\text { ワールスカ) }\end{array}$ & ノニオンポリマー(水素結合) & $\triangle$ & $\triangle$ & $\triangle$ & $\bigcirc$ \\
\hline
\end{tabular}

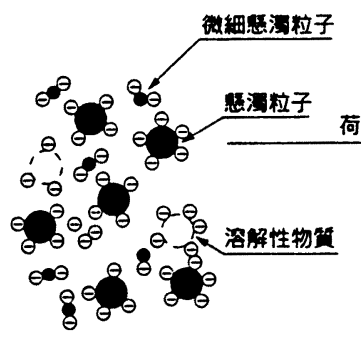

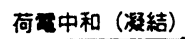
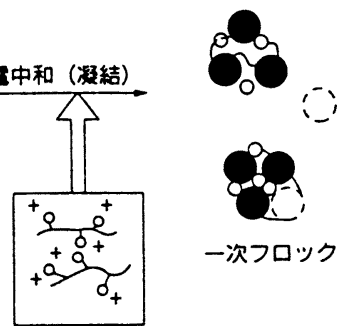

一次フロック
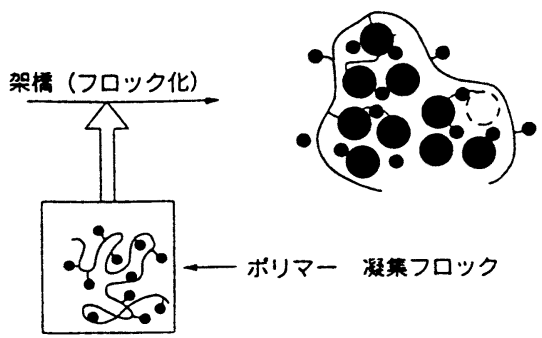

凝盽フロック

ゼータ正位的監剂

図 4 凝集処理の概念図 ${ }^{31}$ 
水 SS も $10 \mathrm{mg} / \mathrm{L}$ 以下で, シャワー水として使用でき るレベルであった。

\section{4 .2 上質古紙}

$\mathrm{SS}$ として $2650 \mathrm{mg} / \mathrm{L}$ の上質古紙脱墨工程の前段白 水を $(\mathrm{pH} \mathrm{8.5)}$ ，ハイホールダー603 $(30 \mathrm{mg} / \mathrm{L})$ と ハイホールダーEA 343 (アニオンポリマー $: 6 \mathrm{mg} / \mathrm{L}$ ) とで加圧浮上処理することにより, SS として $18 \mathrm{mg} /$

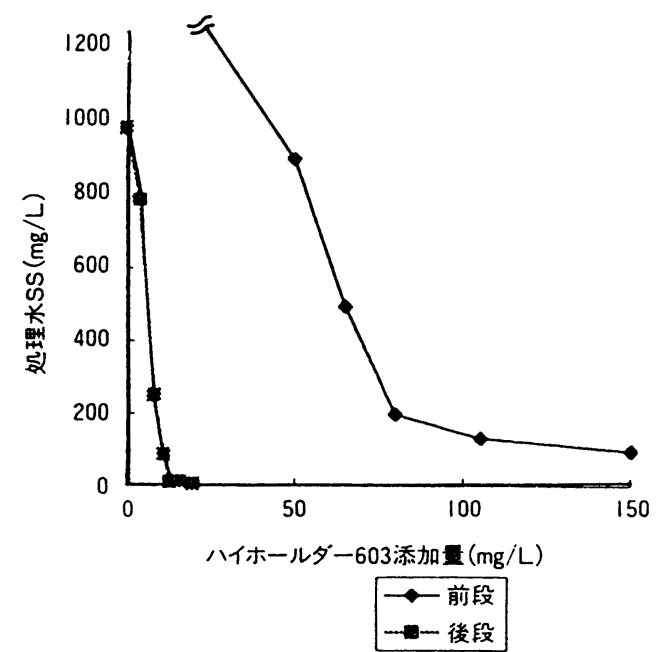

加圧浮上装置 ポセイドン（相川鉄工）

原水水質 前段 $\mathrm{SS}: 1,300 \sim 1,500 \mathrm{mg} / \mathrm{L} \quad \mathrm{pH}: 10.5 \sim 11.0$

後段 SS : $1,000 \sim 1,300 \mathrm{mg} / \mathrm{L} \quad \mathrm{pH}: 9.1 \sim 9.3$

凝集凨 前段 荷電調整剤 ハイホールダー 603

ポリマー ハイホールダー $356: 4 \mathrm{mg} / \mathrm{L}$

後段 荷電調整剤 ハイホールダー 603

ポリマー ハイホールダー $342: 3 \mathrm{mg} / \mathrm{L}$

図 5 脱墨排水の加圧浮上処理効果
Lの良好な処理水が得られた。

3.5 処理水再利用のメリット

図 6 に前段および後段の処理水を再利用した場合の フローを示す。

このようにして排水を処理し再利用した場合, 以下 のメリットが考えられる。

(1)節水および排水処理の負荷軽隇

処理水を脱墨工程の希釈水やシャワー水に再利用 することにより，新水の使用量が低隇できる。排水 量も減り, 排水処理の負荷も軽減できる。

(2)添加薬品の回収

前段白水をそのまま排出している場合と比較して， 硫酸バンドを使わずに（pHを下げずに）インキや 灰分を除去した処理水をパルパー仕込水に使うこと ができ, 苛性ソーダ, 脱墨剤などの添加薬品が再利 用できる。

(3)脱墨パルプの品質向上

脱墨工程の前段, 後段で水を循環使用している場 合, インキや灰分やピッチなどのアニオン性のコロ イド状物質が系内で濃縮し，フローテーションや洗 浄での脱インキ効率を低下させている。前段または 後段の白水を処理し，インキや灰分などのSSを除 去した清浄な水を回収することにより，DIPの白色 度向上，灰分低下，抄紙機でのピッチトラブル低減, ろ水性向上，製品の紙力向上などが期待できる。

表 5 に前段白水処理を想定したテーブルテストの 結果を示す。前段の処理を行うことにより，脱墨パ ルプの白色度が約 $1.5 \%$ 向上した。さらに灰分が $1.4 \%$ 下がることにより, 比引裂強度の増加, フリ

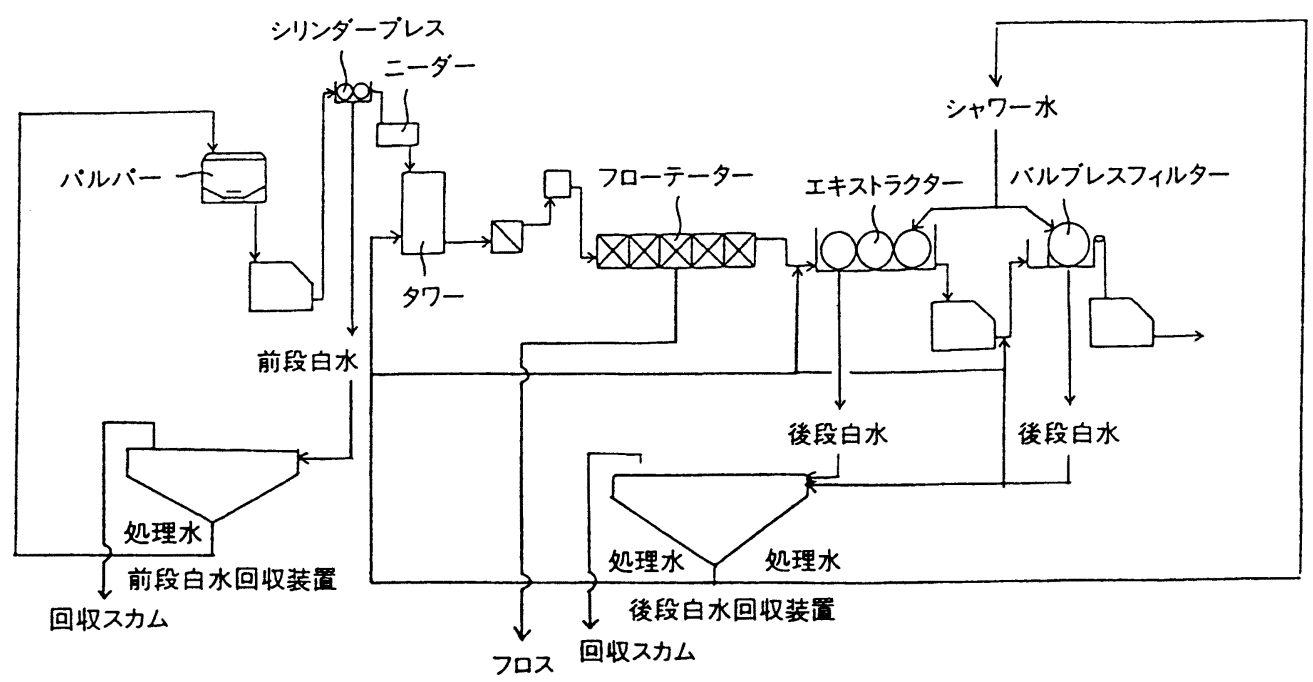

図 6 脱墨工程排水を再利用するフロー 
表 5 処理水使用による DIP の品質改善

\begin{tabular}{c|c|c|c|c|c|c|c}
\hline \multicolumn{3}{c|}{ パルパー希䣋水 } & \multicolumn{6}{|c}{ DIP 品質 } \\
\hline & $\begin{array}{c}\mathrm{SS} \\
(\mathrm{mg} / \mathrm{L})\end{array}$ & $\begin{array}{c}\text { 灰分 } \\
(\mathrm{mg} / \mathrm{L})\end{array}$ & $\begin{array}{c}\text { 白色度 } \\
(\%)\end{array}$ & $\begin{array}{c}\text { 裂断長 } \\
(\mathrm{km})\end{array}$ & $\begin{array}{c}\text { 比引裂き強度 } \\
\left(\mathrm{mN} \cdot \mathrm{m}^{2} / \mathrm{g}\right)\end{array}$ & $\begin{array}{c}\text { 灰分 } \\
(\%)\end{array}$ & $\begin{array}{c}\mathrm{CSF} \\
(\mathrm{ml})\end{array}$ \\
\hline 原 水 & 8,500 & 6,130 & 52.2 & 2.7 & 0.89 & 4.2 & 230 \\
\hline 処理水 & 720 & 410 & 53.8 & 2.6 & 0.96 & 2.8 & 280 \\
\hline
\end{tabular}
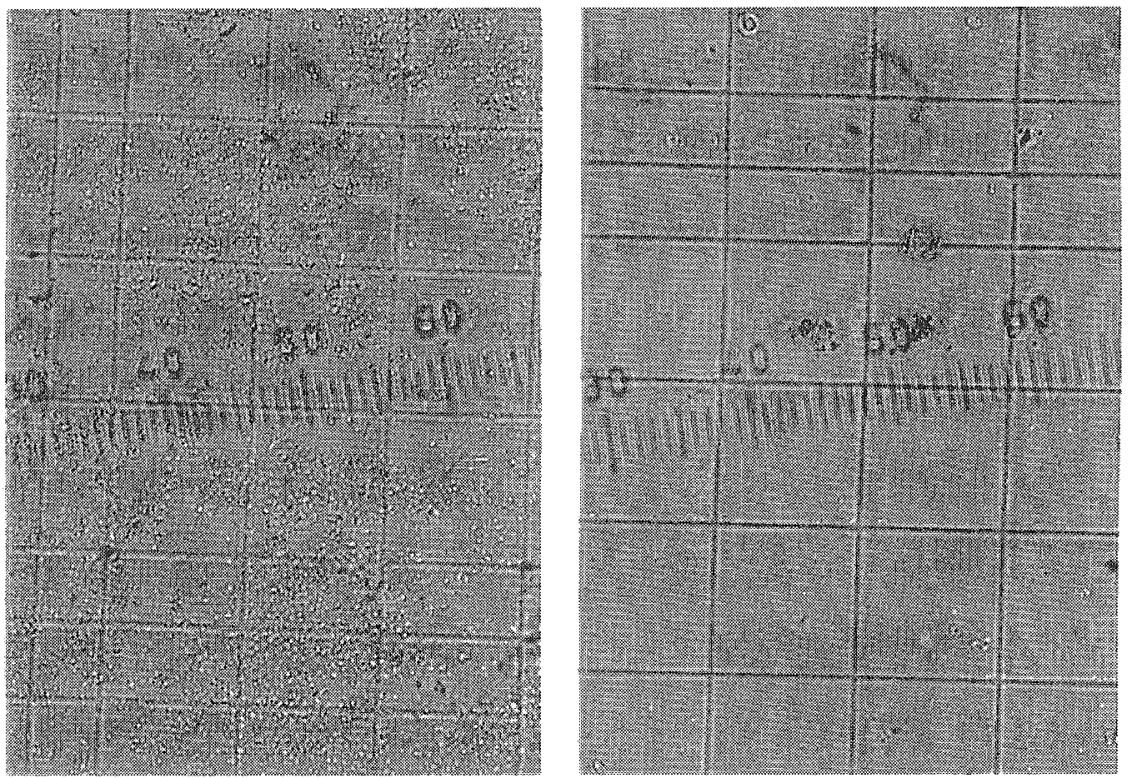

写真 4 ピッチの除去効果（左：処理前, 右：処理後）

一ネスの上昇が得られた。また, 写真 4 にコロイド 状ピッチが減少した様子を示す。

(4)脱墨工程の操業性向上

洗浄機のシャワー水に, 抄紙系の白水回収水や総 合排水の処理水を利用すると，抄紙系や排水処理工 程で使用している硫酸バンド由来のアルミスケール や， $\mathrm{pH}$ 低下によるシリカスケールが発生し，頻繁 にエキストラクターなどの洗浄機を洗浄しなければ ならない場合がある。硫酸バンドを用いずに後段白 水を処理し洗浄機のシャワー水に用いれば，スケー ルの発生が減り, 洗浄回数を減らすことが出来る。 以上の結果, 新水を増やすことなく古紙の配合率を 向上することができ，コストメリットが得られるだけ でなく，地球環境の維持にも寄与できる。

4.おおりに
らず，抄紙工程のスライム障害にも影響を与える。し たがって，障害の影響が少ないといって軽視すべきで はない。

一方, 脱墨パルプの白色度向上において, フローテ ーターでの脱インキ効率は限界にきている。さらに品 質を向上させるためには，清浄な水を回収・再利用し， フローテーターで除去できないコロイド状のインキ粒 子を洗浄, 加圧浮上などで除去する必要がある。脱墨 パルプの歩留を考慮すると困難な課題であるが, 装置 ・薬品を組み合わせた総合技術として完成させたい。

\section{参考文献}

1）日本防菌防バイ学会編：防菌防バイハンドブッ ク, 1986

2）三枝，杉，石田：紙パルプ技術タイムス (6) (1997)

3）杉：紙パ技協誌,51（33）(1997）

パルプ化工程での微生物障害はパルプ化工程のみな 